\title{
EFFECT OF SOME PRACTICES ON ONION BULB PESTS IN FAYOUM GOVERNORATE
}

\author{
SABRA, I. M. \\ Plant Protection Research Institute, ARC, Dokki, Giza
}

(Manuscript received 17 October 2011)

\begin{abstract}
Field and store experiments were curried out in Fayoum governorate, during 2008/9 and 2009/10 seasons to evaluate the role of certain integrated management procedures in the field (planting date, over irrigation and intercropping) and in the store (variety, storage place and onion layer thickness) in reducing infestation percentage of onion bulb pests; Eumerus amoenus Loew, Carpophilus spp., Atherigona orientalis Schin and Ephestia cautella (Walker). Results showed that, the infestation percentages were slightly affected with planting date which were insignificant higher in early planting date in the beginning of November than in the beginning of December, while strongly affected with over irrigation and intercropping which were higher in over irrigated and intercropped treatments than control for the previous pests during both seasons. During storage, infestations were slightly affected with variety during both seasons for the first three pests, while it was significant higher on Behery var. than Giza 20 var. during the first season for $E$. cautella only. The bulbs infestation percentages for $E$. amoenus, Carpophilus spp.and A. orientalis in case of indoor treatment were significantly lower than in outdoor treatment during both seasons, with exception of $E$. cautella only. Also increasing layer thickness of bulbs in the store $(60 \mathrm{~cm}$.), increased the infestation percentage for the first three pests while reducing the infestation percentage of $E$. cautella during both seasons. Regardless of variety the results emphases that prevent of water stress and intercropping after bulb formation in the field and storing onion bulbs in aired and shaded store with $30 \mathrm{~cm}$ height were useful to reduce infestation of onion bulb pests during storage.
\end{abstract}

\section{INTRODUCTION}

Onion Alium cepa L. is attacked in the Fayoum with four insect pests in the field namely: Eumerus amoenus Loew (Diptera : Syrphidae), Carpophilus spp. [C. immaculatus Luc., C. hemipterus L.] (Coleoptera: Nitidulidae), Atherigona orientalis Schin (Diptera : Muscidae) and the infestation continue in the stores in addition to Ephestia cautella (Walker), (Lepidoptera : Phycitidae). These insect pests cause reduction in quantity and quality of onion bulbs. The estimated weight loss ranged from 25.78 to $24.10 \%$ (Sabra et al, 2011, Abu-Hashish, 1998). Also, Gupta et al, 1991, reported that $A$. orientalis and Carpophilus spp. caused yield losses to stored 
onion in India. Because onion bulbs not only freshly consumed but also stored bulbs consumed all the year round, it is important to ensure good quality bulbs and produce healthy bulb yields for storage for a long period, so management considerations of pest control must be taken both in the field and in the store.

The present study aims to evaluate the role of certain IPM procedures in the field (planting date, over irrigation and intercropping) and others in the store (variety, storage place and onion layer thickness) on reducing yield losses caused by onion bulb pests after bulbs formation in the field and during storage under Fayoum conditions.

\section{MATERIALS AND METHODS}

IBM procedures were tested against onion bulb insects in onion field and store in Fayoum Governorate, during 2008/2009 and 2009/2010 seasons. The experiments were started in the field and continued in the store.

\section{A- Field Experiments:}

An area of about $1 / 2$ fed. was divided into five equal plots (replicates), each contained four equal subplots represented the treatments:

1- Control:

Its subplots were planted with onion seedlings (Giza 20 var.) at the recommended date (end of November).

2- Planting date:

The five replicates of this treatment were planted one month after the control at the end of December.

\section{3- Over irrigation:}

More irrigation was followed every two weeks instead of three weeks during the period from beginning of March till end of April.

\section{4- Intercropping}

In this treatment, the subplots of onion plants were intercropped with maize at the beginning of April. The intercropped subplots received excesses of water irrigation especially during maize planting till harvest while the irrigation in the control was ended one month earlier.

All another agricultural practices were normally done with no application of any insecticides. At harvest time (end of May), 100 bulbs were randomly collected from each subplot and transferred to the laboratory for examination to record numbers of healthy and infested bulbs with insect pests under study. 


\section{B- Store Experiments:}

Three experiments were conducted during the storage period from the beginning of June to the end of October, as follows:

1. Variety Experiment:

Bulbs of two onion varieties (Giza 20 \& Behery) were stored at aired; shaded stores. The bulbs were kept in piles, each measured $2 \mathrm{~m}$. wide $\times 10 \mathrm{~m}$. long $\times 60 \mathrm{~cm}$. height. In the beginning of August, five biweekly samples of 100 bulbs each were randomly collected from each variety and investigated to count the numbers of healthy and infested bulbs as well as the numbers of main insect pests.

2. Storage Place Experiment:

Onion bulbs of Giza 20 variety were stored under two conditions:

a- Aired shaded store (indoor)

b- Open field store (outdoor).

In the open storage case, the bulbs were kept in piles similar to that described before and covered with dry rice straws. In the indoor store, bulbs were also stored in similar piles. Five biweekly samples each contains 100 bulbs from each site were randomly collected and examined to record numbers of healthy and infested bulbs as well as numbers of insect pests per infested bulb.

3. Onion layer thickness:

After harvest the bulbs were stored in pills of two thicknesses (30 and $60 \mathrm{~cm}$.) at the beginning of June in aired and shaded store. Five samples of 100 bulbs from each storage thickness were randomly taken biweekly and examined carefully against the insect infestations, as mentioned before.

\section{RESULTS AND DISCUSSION}

\section{A. Effect of field treatments on the infestation:}

1. Planting date:

As shown in Table (1), three insects infested onion bulbs in the field were recorded; E. amoenus, Carpophilus spp. and A. orientalis while E. cautella infest onion only on the store. Venkatesh and David, 2001, reported that E. cautella infest onion bulbs in store probably with decrease in relative contents of moisture, pyruvic acid and total sulfur.

The present study revealed that, these insects (regardless of species) not significantly affected by planting date. Whereas the infestation in the early plantation (control) ranged $5.4-18.0 \%$ in the $1^{\text {st }}$ season and $7.8-20.2 \%$ in the second season. While in the late plantation date it ranged $8.0-21.0 \%$ and $10.0-22.4 \%$, in 
the two seasons, respectively. These results pointed to that, delaying the recommended plantation date, for one month increased the infestation with the three aforementioned insects in both seasons. In this respect, Haydar and El-Sherif (1990), reported that, the onion plants of early planting date (beginning of November) were less susceptible to the infestation by insect pests.

Table 1. Percent of bulbs infested with three insects under three agricultural field practices during 2008/9 and 2009/10 seasons.

\begin{tabular}{|c|c|c|c|c|c|c|c|}
\hline \multicolumn{8}{|c|}{ Infested bulbs \% } \\
\hline \multirow{2}{*}{ Season } & \multicolumn{3}{|c|}{ E. amoenus } & \multicolumn{2}{|c|}{ A. orientalis } & \multicolumn{2}{|c|}{ Carpophilus spp. } \\
\hline & & Control & Treatment & Control & Treatment & Control & Treatment \\
\hline \multicolumn{8}{|c|}{ Planting date } \\
\hline \multirow{2}{*}{$2008 / 2009$} & $\mathrm{x}$ & 18.0 & 21.0 & 9.4 & 15.0 & 5.4 & 8.0 \\
\hline & $\mathrm{t}$ & \multicolumn{2}{|c|}{1.65} & \multicolumn{2}{|c|}{1.86} & \multicolumn{2}{|c|}{1.96} \\
\hline \multirow{2}{*}{$2009 / 2010$} & $\mathrm{x}$ & 20.2 & 22.4 & 11.2 & 14.0 & 7.8 & 10.0 \\
\hline & $\mathrm{t}$ & \multicolumn{2}{|c|}{0.73} & \multicolumn{2}{|c|}{0.92} & \multicolumn{2}{|c|}{1.47} \\
\hline \multicolumn{8}{|c|}{ Irrigation } \\
\hline \multirow{2}{*}{$2008 / 2009$} & $x$ & 18.0 & 27.0 & 9.4 & 17.4 & 5.4 & 9.0 \\
\hline & $\mathrm{t}$ & \multicolumn{2}{|c|}{$2.36 *$} & \multicolumn{2}{|c|}{$2.38 *$} & \multicolumn{2}{|c|}{$2.57 *$} \\
\hline \multirow{2}{*}{$2009 / 2010$} & $x$ & 20.2 & 29.0 & 11.2 & 19.0 & 7.8 & 12.4 \\
\hline & $\mathrm{t}$ & \multicolumn{2}{|c|}{$2.40 *$} & \multicolumn{2}{|c|}{$2.39 *$} & \multicolumn{2}{|c|}{$2.36 *$} \\
\hline \multicolumn{8}{|c|}{ Intercropping } \\
\hline \multirow{2}{*}{$2008 / 2009$} & $x$ & 18.0 & 25.4 & 9.4 & 16.6 & 5.4 & 8.8 \\
\hline & $\mathrm{t}$ & \multicolumn{2}{|c|}{$4.23 *$} & \multicolumn{2}{|c|}{$2.30 *$} & \multicolumn{2}{|c|}{$2.61 *$} \\
\hline \multirow{2}{*}{$2009 / 2010$} & $\mathrm{x}$ & 20.2 & 27.2 & 11.2 & 16.8 & 7.8 & 12.0 \\
\hline & $\mathrm{t}$ & \multicolumn{2}{|c|}{$3.38^{*}$} & \multicolumn{2}{|c|}{$2.48^{*}$} & \multicolumn{2}{|c|}{$2.45 *$} \\
\hline
\end{tabular}

$\mathrm{t}_{8}=2.30$

\section{Irrigation}

Data presented in table (1) revealed that, onion bulbs of the over irrigated area were subject to a higher infestation with $E$. amoenus, $A$. orientalis and Carpophilus spp. than those of the control. In the first season the infestation percentages with these insects were 18.0, 9.4 and 5.4\% in the control and 27.0, 17.4 and $9.0 \%$ in the treatment, respectively. In the second season, these percentages were $20.2,11.2$ and $7.8 \%$ for control and $29.0,19.0$ and $12.4 \%$ for the over irrigated area, respectively. Statistical analysis revealed that excess irrigation for onion fields, significantly increased the infestation with the three previous insects. This result was acceptable because onion bulbs that exposed to water stress became more susceptible to infect with rots and attract these pests. Schwartz (2011), mentioned that, water stress, especially near harvest, increased infection with bulb rot during storage. Also, Lomonaco and Almeida (1995) found that, A. orientalis was the most frequent species in decomposing onions. 


\section{3- Intercropping}

The data presented in the same previous table showed that, intercropping process significantly increased the infestation with the three insects; $25.4-27.2,16.6$ -16.8 and $8.8-12.0 \%$ for the treatment and $18.0-20.2,9.4-11.2$ and $5.4-7.8 \%$ for the control in 2008/9 and 2009/10 seasons, respectively. In general, during intercropping process the water stress and mechanical damage during plantation clearly make the bulbs more susceptible to the infestation with the previous insect pests. In this respect, Mahmoud (2008) reported that, the mechanical wounded bulbs indicated higher infestation with $E$. amoenus which was 4-5 times as healthy bulbs in store.

\section{B. Effect of storage treatments on the infestation:}

\section{Variety:}

Data given in Table (2) showed that, throughout 2008/9 and 2009/10 seasons, the infestation with $E$. amoenus and $E$. cautella were relatively higher for Behery than Giza 20 variety. It ranged regardless of season, 18.6 - 23.0 and 18.0 $20.2 \%$ for E. amoenus and $13.2-20.2$ and $12.4-16.2 \%$ for $E$. cautella in the onion varieties, respectively. In contrast, these percentages were slightly higher for $A$ orientalis and Carpophilus spp for Giza 20 than Behery var.; $6.2 \& 4.2$ and $4.8 \& 3.8 \%$ for $A$. orientalis and 12.2\&13.4 and 11.2 and 10.2\% for Carpophilus spp. in 2008/9 and 2009/10 seasons, respectively (Table 2). Statistical analysis emphasis that, susceptibility of the two varieties against the infestation with these insects was not significantly differed except for E. cautella during the first season only.

\section{Storage place:}

Based upon the data presented in Table (2), the numbers of infested bulbs were higher in case of outdoor than in indoor stored onions during both seasons for all insects except $E$. cautella. In outdoor treatment, the percent of infestations with $E$. amoenus, $A$. orientalis and Carpophilus spp were 24.6, 7.0 and $16.4 \%$ in the first season and $21.2,8.4$ and $18.0 \%$ in the second season, respectively. In case of indoor treatment, these findings were lower; $17.4,4.2$ and $10.2 \%$ in the first season and $15.2,5.0$ and $12.6 \%$ in the second season for the three considered insect pests, respectively. On the other hand, the infestation with the fourth insect ( $E$. cautella) was higher $(23.2 \& 16.0 \%)$ in the indoor treatment than that in the outdoor (18.8 \&12.2\%). Statistical analysis revealed that, the percent of infested bulbs were strongly affected by storage place, the indoor store had lower infestation than outdoor one for all studied insect pests. Mahmoud, et al, 2007, found that, the infestation of stored onion bulbs with $E$. amoenus was lower in indoor than outdoor treatment. 
Table 2. Percent of bulbs infested with four insects under three storage treatments during 2008/9 and 2009/10 seasons.

\begin{tabular}{|c|c|c|c|c|c|c|c|c|c|}
\hline & \multicolumn{9}{|c|}{ Infested bulbs \% } \\
\hline & \multicolumn{3}{|c|}{ E. amoenus } & \multicolumn{2}{|c|}{ A. orientalis } & \multicolumn{2}{|c|}{ Carpophilus spp. } & \multicolumn{2}{|c|}{ E. cautella } \\
\hline \multicolumn{10}{|c|}{ Variety } \\
\hline \multirow{3}{*}{$2008 / 2009$} & & Giza 20 & Behery & Giza 20 & Behery & Giza 20 & Behery & Giza 20 & Behery \\
\hline & $x$ & 20.2 & 23.0 & 6.2 & 4.8 & 12.2 & 11.2 & 16.2 & 20.2 \\
\hline & $\mathrm{t}$ & \multicolumn{2}{|c|}{1.56} & \multicolumn{2}{|c|}{0.52} & \multicolumn{2}{|c|}{0.56} & & 2.66* \\
\hline \multirow{2}{*}{$2009 / 2010$} & $x$ & 18.0 & 18.6 & 4.2 & 3.8 & 13.4 & 10.2 & 12.4 & 13.2 \\
\hline & $\mathrm{t}$ & \multicolumn{2}{|c|}{0.35} & \multicolumn{2}{|c|}{0.45} & \multicolumn{2}{|c|}{1.74} & \multicolumn{2}{|c|}{0.45} \\
\hline \multicolumn{10}{|c|}{ Storage place } \\
\hline \multirow{3}{*}{$2008 / 2009$} & & Outdoor & Indoor & Outdoor & Indoor & Outdoor & Indoor & Outdoor & Indoor \\
\hline & $\mathrm{x}$ & 24.6 & 17.4 & 7.0 & 4.2 & 16.4 & 10.2 & 18.8 & 23.2 \\
\hline & $\mathrm{t}$ & \multicolumn{2}{|c|}{$4.01^{*}$} & \multicolumn{2}{|c|}{$2.89 *$} & \multicolumn{2}{|c|}{$2.67 *$} & \multicolumn{2}{|c|}{$2.98^{*}$} \\
\hline \multirow{2}{*}{$2009 / 2010$} & $x$ & 21.2 & 15.2 & 8.4 & 5.0 & 18.0 & 12.6 & 12.2 & 16.0 \\
\hline & $\mathrm{t}$ & \multicolumn{2}{|c|}{ 3.89* } & \multicolumn{2}{|c|}{$5.01^{*}$} & \multicolumn{2}{|c|}{$3.76^{*}$} & \multicolumn{2}{|c|}{$3.41^{*}$} \\
\hline \multicolumn{10}{|c|}{ Onion layer thickness } \\
\hline \multirow{3}{*}{$2008 / 2009$} & & $30 \mathrm{~cm}$. & $60 \mathrm{~cm}$. & $30 \mathrm{~cm}$. & $60 \mathrm{~cm}$. & $30 \mathrm{~cm}$. & $60 \mathrm{~cm}$. & $30 \mathrm{~cm}$. & $60 \mathrm{~cm}$. \\
\hline & $x$ & 21.6 & 25.4 & 3.6 & 6.6 & 8.8 & 10.0 & 26.8 & 18.4 \\
\hline & $\mathrm{t}$ & \multicolumn{2}{|c|}{1.27} & \multicolumn{2}{|c|}{$3.81^{*}$} & \multicolumn{2}{|c|}{1.08} & \multicolumn{2}{|c|}{$4.37^{*}$} \\
\hline \multirow{2}{*}{$2009 / 2010$} & $x$ & 22.8 & 26.0 & 4.4 & 7.0 & 7.8 & 9.2 & 17.4 & 12.4 \\
\hline & $\mathrm{t}$ & \multicolumn{2}{|c|}{1.57} & & & & & & \\
\hline
\end{tabular}

$\mathrm{t}_{8}=2.30$ 


\section{Onion layer thickness}

As shown in Table (2), increasing of bulb layer sickness in the store $(60 \mathrm{~cm}$.$) ,$ increased the infestation with $E$. amoenus, $A$. orientalis and Carpophilus spp, while reduced the infestation with $E$. cautella during both seasons. The infestation percentages for $60 \mathrm{~cm}$. treatment were $25.4 \& 26.0 \%, 6.687 .0 \%, 10.0 \& 9.2 \%$ and $18.4 \& 12.4 \%$ in $2008 / 9$ and $2009 / 10$ season, respectively. These percentages were $21.6 \& 22.8 \%, 3.6 \& 4.4 \%, 8.8 \& 7.8 \%$ and $26.8 \& 17.4 \%$ for $30 \mathrm{~cm}$. treatment in both seasons, respectively. T-test explained insignificant differences between thin $(30 \mathrm{~cm}$.) and thick layer $(60 \mathrm{~cm}$.) for the infestation with $E$. amoenus and that with Carpophilus $s p p$. On the other hand, these differences were significant for $A$. orientalis and $E$. cautella throughout both seasons. These results explained that, the three stored onion insects; E. amoenus A. orientalis and Carpophilus spp. Prefer thick layer (6.6-26.0\% infestation) than thin layer $(3.6-22.8 \%)$ for attacking the bulbs. The opposite was happened with $E$. cautella which preferred the onion thin layers than those sick ones, $17.4-26.8$ and 12.4 - 18.4\% infestation, respectively. In general, all results illustrated in Table (2) indicated that, regardless of onion variety, storing the bulbs in indoor in thin layers $(30 \mathrm{~cm}$.) reduced the infestation with various tested insects.

\section{REFERENCES}

1. Abu-Hashish, T. A. 1998. Monthly population density and laboratory rearing of Carpophilus hemipterus (L.) (Coleoptera: Nitidulidae) on onion prepared for exportation and dehydration. Ann. Of Agric. Sc., Moshtohor. 36 (3): 1969-1980.

2. Gupta, R. P., K. J. Srivastava and U. B. Pandey. 1991. Management of onion diseases and insect pests in India. Onion Newsletter for the Tropics. 3: 15-17.

3. Haydar, M. F. and L.S. El-Sherif. 1990. Ecological aspects and developing method of onion pest control. Bull. Soc. Entomol. Egypt, econ. Ser., 16: 119-126.

4. Lomonaco, C. and J. R. Almeida. 1995. Seasonality and use of resources for feeding and oviposition of muscoid Diptera in Jacarepagua sand dunes, Rio de Janeiro, Brazil. Revista Brasileira de Entomologia. 39 (4): 883-890.

5. Mahmoud, H. H. 2008. Ecological studies on certain insect pests of onion with special emphasis on the onion bulb fly Eumerus amoenus Loew. (Diptera : Syrphidae). Ph.D. Thesis, Fac. Agric., Cairo Univ., Egypt.

6. Mahmoud, H. H., S. I. El-Sherif, H. A. El-Shabrawy and S. A. Mourad. 2007. Infestation of onion bulbs with Eumerus amoenus Loew. (Diptera: Syrphidae) during storage. Bul. Fac. Agric., Cairo Univ. 58 (1): 86-91.

7. Sabra, I. M., H. A. Saleh and I. A. EL Sappagh. 2011. Further studies on the main onion insects in store and their effect on yield loss in Fayoum. (under publication)

8. Schwartz H. F. 2011. Botrytis, Downy Mildew and Purple Blotch of Onion. Colorado Onion Production and IPM Bulletin, 547A.

9. Venkatesh, D. and P. M. M. David. 2001. Some observations on the fig moth, Cadra cautella (Wlk.) infesting onions in storage. Entomon. 26 (3/4) 323-326.

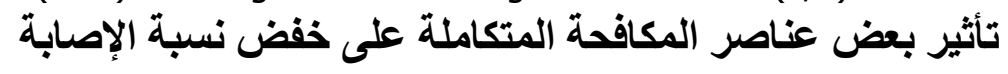




\title{
بالآفات الحثرية التي تصيب البصل بمحافظة الفيوم
}

\author{
ابراهيم مخيمر صبرة \\ مركز البحوث الزراعية , معهد بحوث وقاية النباتات , الدقي - جيزة
}

أجريت تجربتان احداهما في الحقل والاخرى في المخزن لتقييم دور بعض الاجراءات

كعناصر للمكافحة المتكاملة في خفض نسبة الإصابة بالآفات الحشرية التي تصيب البصل بعد مرحلة تكوين الابصال في الحقل (ميعاد الزراعة ـ التحميل - زيادة ماء الري) وخلال فترة التخزين (الصنف - مكان التخزين - سمك طبقة التخزين) تحت ظروف محافظة الفيوم خلال موسمي و2010/2009 وهذه الافات هي ذبابة البصل الكبيرة Eumerus amoenus Loew وخنافس فئس الفاكهة المجفة Carpophilus spp وذبابة الأزريجونا Atherigona orientalis Schin. في الحقل و المخزن بالاضافة الى فر اشة البلحEphestia cautella (Walker) التي تصيبه في المخزن فقط.

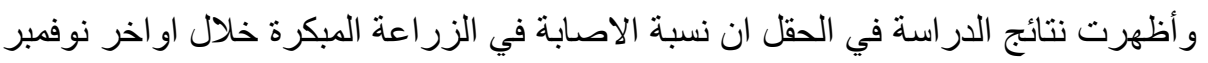

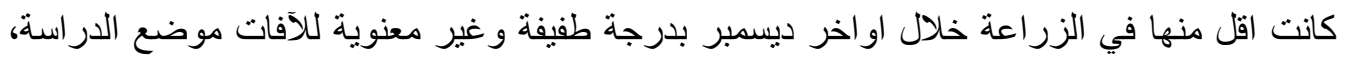

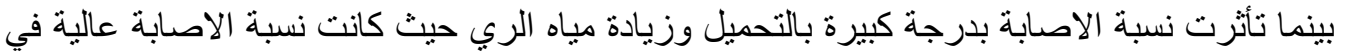
المساحات المحملة خلال موسمي الدراسة وكذلك في المساحات التي بها زيادة ماء الكاء الري مقارئنة

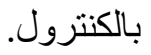

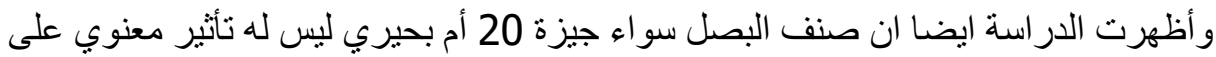

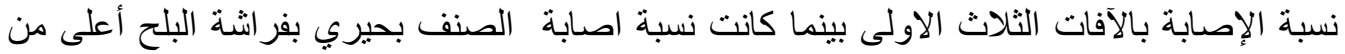
جيزة 20 خلال الموسم الاول فقط حيث كانت الأختلافات معنوية. اما بالنسبة لمكان التخزين فكانت

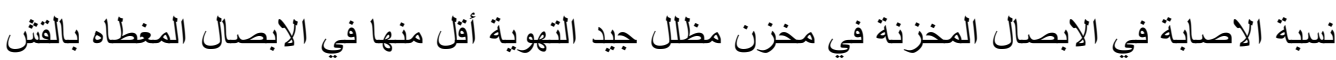
المخزنة في الحقل المكثوف وكان الأختلاف معنويا بالنسة للثلاثة افات الاولى خلال موسمي الدراسة و على العكس من ذللك تبين ان نسبة الاصابة كانت أقل في الحقل المكثوف عنها في المخزن بالنسبة

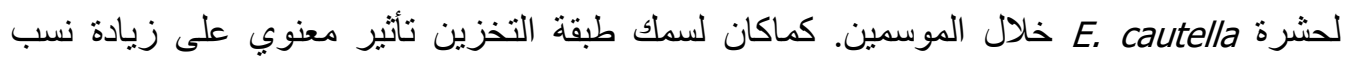

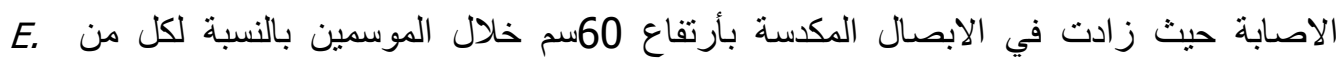
Carpophilus spp و A. orientalis و amoenus العكس من ذلك وجد ان الاصابة بحشرة E. cautella كانت أقل في الابصال المكدسة (60سم) عنها في

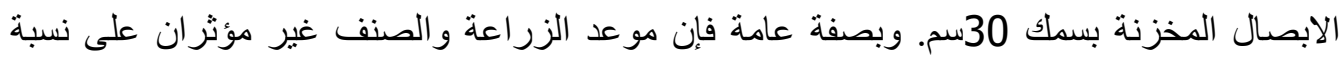

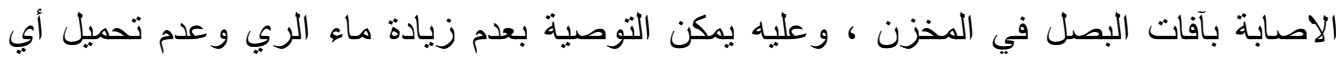

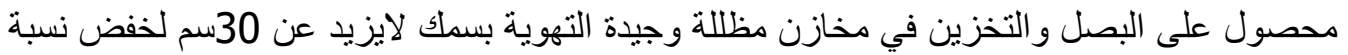
الإصـابة بالآفات الحشرية في المخزن. 